\title{
Analysis of Probable Flows Based on the Rainfall-Runoff Model for Flood Scenarios: a Case Study of the Losse River Catchment (Germany)
}

\author{
Mariusz Pawel Barszcz* \\ Department of Hydraulic Engineering, Warsaw University of Life Sciences - SGGW, \\ Nowoursynowska 159, 02-776 Warsaw, Poland
}

Received: 17 December 2015

Accepted: 15 February 2016

\begin{abstract}
The procedure of the rainfall-runoff (R-R) model, based on the instantaneous unit hydrograph (IUH) method and used to calculate the probable flows in 8 profiles of the Losse river (on the stretch from $5+476$ to $7+596 \mathrm{~km}$ ) for three flood scenarios (Qextreme, Q1\% and Q10\%), has been presented in this work. A computer program developed by the author was used to conduct the analyses, enabling the flows to be simultaneously calculated for each of the analyzed profiles in response to 10 rainfall events of varying duration and a given exceedance probability.

The obtained values of probable flows were recalculated into corresponding water table levels using the WSP-ASS program (Water Level Program). The extent of the flooding and water depths for three flood scenarios were calculated based on the levels of the water table and terrain elevation data ("Digital Terrain Model"). As a final effect of the analyses, flood hazard maps for the analyzed stretch of the Losse River were constructed, enabling the consequences of flooding to business activities, the infrastructure, the environment, and human health and life to be assessed.
\end{abstract}

Keywords: consequences of flooding, flood hazard maps, flood scenarios, probable flows, water table levels

\section{Introduction}

Directive 2007/60/EC [1] sets the framework of actions aimed at restricting the negative consequences connected with floods within the European Union. The implementation of the Directive in the Polish legal system was

*e-mail: mariusz_barszcz@sggw.pl regulated by the amended "Water Law" Act of 5 January 2011 [2], which required member states to construct flood hazard maps and flood risk maps showing the potential adverse consequences associated with different flood scenarios by December 2013. Some of the first EU projects testing the methodology of developing such maps were the LABEL [3] and Flood Wise projects [4]. The methodology for compiling such maps in Poland was specified by a regulation [5]. Flood hazard maps contain information 
about the extent of flooding and water depths associated with different flood scenarios (sometimes together with flow velocity and direction of flow), whereas flood risk maps contain additional information about the expected consequences of these scenarios (e.g., economic damage and the number of people affected) [6].

Constructing such maps requires the probable flows in particular profiles of the analyzed river to be established as well as their corresponding water table levels. Hydrometric measurements, on the basis of which the value of probable flows can be calculated (especially those with a small probability), are taken in relatively few small and medium-sized catchment areas. The flood probabilities used in each of the member states may vary according to the local conditions or circumstances. The work of Müller [7] provided information regarding the probabilities accepted for the flood scenarios, which were then used to prepare flood risk maps in selected member states. The basic methodology of developing flood risk management plans in Germany, including flood threat and flood risk maps, was prepared by the LAWA working group $[8,9]$. On this basis, each of the federal states of Germany prepared its own detailed methodology for the implementation of Directive 2007/60/EC.

The extent of flooding and water depth, both of which are elements of flood hazard and flood risk maps, can be determined using different methods. Most often, these elements are indicated in the analysis using hydraulic models [10-16]. To make the application of these models possible, one must calculate flows with a given probability. Serving as an example, regional flood frequency analysis, which was then used in the hydraulic model to determine the area of flood hazard, was applied in [11]. In [17], a map of flood risk was developed based on analyses using the hydrological and hydraulic models simultaneously. Geographical information system (GIS) tools are often applied in analyses aimed at preparing a flood risk map $[10,18-21]$.

This work presents the procedure of the rainfall-runoff (R-R) model that is used to calculate the probable flows in eight profiles of the Losse River (on the stretch from $5+476$ to $7+596 \mathrm{~km}$ ) for three flood scenarios. A computer program developed by the author was used to conduct the analysis. It was accepted that the calculated flows, with a given exceedance probability and induced by a critical rainfall duration, have the same probability of occurring as the rainfall events that brought them on. Verification of the conceptual $R-R$ model, based on Nash's instantaneous unit hydrograph [22], was conducted using flow values measured in the Helsa River profile $(15+700 \mathrm{~km})$.

Water table levels that correspond to the established values of probable flow were calculated in the German State of Hesse using the WSP-ASS water level program. The extent of the flooding and water depth for three flood scenarios were calculated based on the levels of the water table and terrain elevation data ("Digital Terrain Model"). These calculations were conducted using the ArcMap program (GIS software).

The flood scenarios for the Losse River catchment (Table 1) accepted for analyses were compiled along with scenarios formulated in the EU Floods Directive [1] and those analyzed by the Department Hydraulic Engineering and Water Resources Management at the University Kassel for the Fulda River catchment [23-25]. The final effect of the analyses was the construction of flood hazard maps for the analyzed stretch of the Losse River, for which a high risk of flooding was established based on preliminary flood risk assessment.

\section{Methods and Materials}

\section{Characteristics of the Catchment Area}

The analysis pertained to the Losse River catchment located in Hesse. The Losse (Fig. 1) flows into the Fulda (a tributary of the Weser) within the city limits of Kassel. The upper part of the catchment is characterized by upland and sub-alpine landscapes, while the remaining parts are lowlands. The highest and lowest points in the catchment range from 565 to $135 \mathrm{~m}$.a.s.l. The average slope of the catchment is $3.8 \%$.

The analyses presented in the work covered the subcatchments of the Losse within the limits of three main calculation profiles, i.e., the upper and lower profile, and the Helsa profile (within the Helsa city limits), in which measurements of the water depths and flows are taken (Fig. 2). The upper and lower profiles determine the extent of the analyzed stretch of a river for which hazard risk maps have been constructed. Table 2 presents selected characteristics of the subcatchments, defined by the main calculation profiles.

Table 3 presents the values of areas occupied by different types of land use in the subcatchments as established from analysis of aerial photographs using ArcMap. The individual subcatchments are characterized

Table 1. Flood scenarios for the analyzed Losse River catchment and according to other sources.

\begin{tabular}{|c|c|c|}
\hline Directive 2007/60/WE & Fulda River Catchment & Losse River Catchment \\
\hline $\begin{array}{l}\text { floods with a low probability, } \\
\text { or extreme event scenarios }\end{array}$ & extreme flood: $\mathrm{Q}_{1 \%} \cdot 1.3$ & extreme flood: $\mathrm{Q}_{\text {extreme }}($ Scenario 1) \\
\hline $\begin{array}{l}\text { floods with a medium probability } \\
\text { (likely return period } \geq 100 \text { years) }\end{array}$ & medium probability of flood: flow $\mathrm{Q}_{1 \%}$ & $\begin{array}{c}\text { medium probability of flood: flow } \mathrm{Q}_{1 \%} \\
\text { (Scenario } 2 \text { ) }\end{array}$ \\
\hline $\begin{array}{c}\text { floods with a high probability, } \\
\text { where appropriate }\end{array}$ & high probability of flood: flow $\mathrm{Q}_{10 \%}$ & $\begin{array}{l}\text { high probability of flood: flow } \mathrm{Q}_{10 \%} \\
\text { (Scenario 3) }\end{array}$ \\
\hline
\end{tabular}



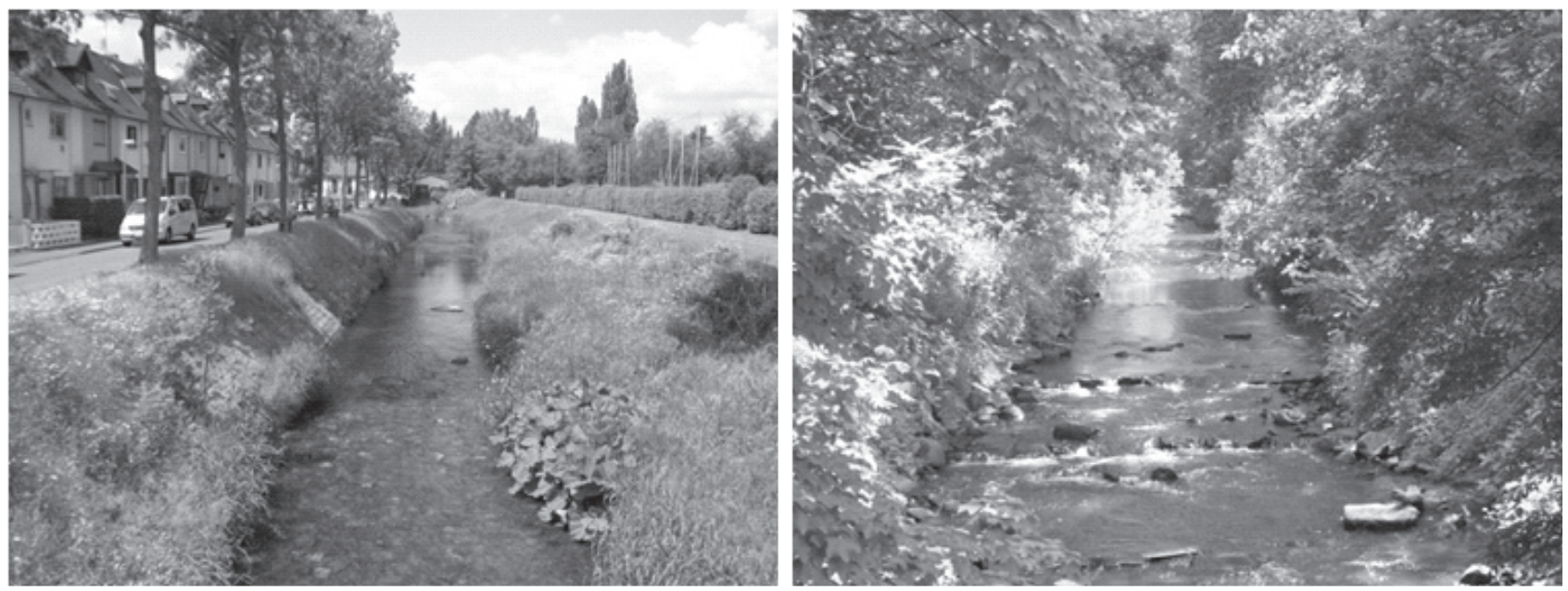

Fig. 1. Stretches of the Losse River in urbanized (residential) and forest areas.

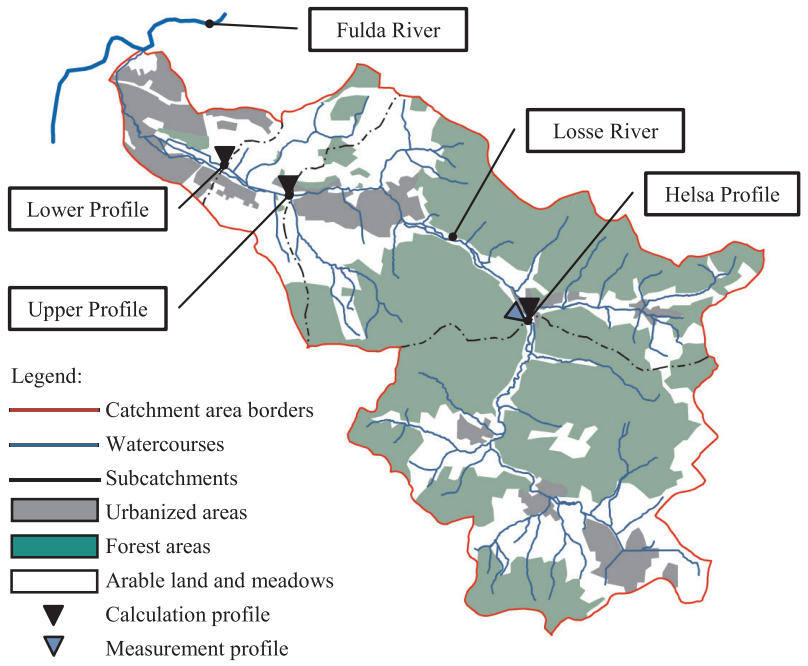

Fig. 2. Location of the main calculation profiles and distribution of various land uses within the catchment.

Table 2. Basic characteristics in relation to the main calculation profiles.

\begin{tabular}{|c|c|c|c|}
\hline Features & $\begin{array}{c}\text { Lower } \\
\text { Profile }\end{array}$ & $\begin{array}{c}\text { Upper } \\
\text { Profile }\end{array}$ & $\begin{array}{c}\text { Helsa } \\
\text { Profile }\end{array}$ \\
\hline Kilometer of the river $(\mathrm{km})$ & $5+476$ & $7+596$ & $15+700$ \\
\hline $\begin{array}{c}\text { Length of river from the } \\
\text { profile to the drainage } \\
\text { divide }(\mathrm{km})\end{array}$ & 23.1 & 21.0 & 12.7 \\
\hline $\begin{array}{c}\text { Surface area of } \\
\text { subcatchments }\left(\mathrm{km}^{2}\right)\end{array}$ & 116.2 & 97.0 & 53.8 \\
\hline
\end{tabular}

by a high percentage of forested areas, ranging from 58.9 do $63.2 \%$. At approximately $8.5 \%$, the percentage of urbanized areas (industrial and residential land) is similar in the analyzed subcatchments.
Table 3. Areas of land occupied by different types of land use in the individual subcatchments.

\begin{tabular}{|c|c|c|c|}
\hline \multirow{2}{*}{ Type of land use } & $\begin{array}{c}\text { Lower } \\
\text { profile }\end{array}$ & $\begin{array}{c}\text { Upper } \\
\text { profile }\end{array}$ & $\begin{array}{c}\text { Helsa } \\
\text { profile }\end{array}$ \\
\cline { 2 - 4 } & \multicolumn{3}{|c|}{ Percentage area (\%) } \\
\hline Forests & 58.9 & 63.2 & 62.2 \\
\hline Arable Land & 16.7 & 12.4 & 12.9 \\
\hline Meadows & 13.7 & 12.9 & 13.4 \\
\hline Industrial Areas & 2.0 & 1.7 & 2.6 \\
\hline Residential Areas & 6.4 & 6.8 & 5.8 \\
\hline Other & 2.3 & 3.0 & 3.1 \\
\hline
\end{tabular}

\section{Rainfall-Runoff Model Procedure}

The probable flows analyzed in the work were established based on the $R-R$ model using Nash's instantaneous unit hydrograph method $[22,26]$ to convert rainfall into runoff. It was assumed that the calculated flows of a given exceedance probability, which correspond to the flood scenarios (Table 1), have the same probability of occurring as the rainfalls that induced them.

The rainfall-runoff procedure leading to the calculation of probable flows in selected profiles of the Losse was programmed into a computer program developed by the author (using $\mathrm{C}++$ programming language). This program facilitated the analysis of individual elements of the procedure for 10 rainfalls and all calculation profiles (limiting the subcatchments) simultaneously, in the following order:

- Rainfall durations (calculation/choice ${ }^{1}$ options: times provided by the user; rainfall duration equal to the time of concentration, calculated from the Kreps model [27]).

\footnotetext{
Options indicated first in the brackets within the program (model) procedure were ultimately accepted for calculating probable flows used to construct flood hazard maps.
} 
- Exceedance probability for the analyzed rainfalls.

- Total rainfall depths of rainfall events of a given probability and varying durations (total rainfall provided by the user, rainfall depths provided by the user at given time intervals of the rainfall event, and calculating the maximum total rainfall from the model proposed by Bogdanowicz and Stachý [28]).

- Distribution of rainfall depth over the course of the rainfall event (German Association for Water, Wastewater and Waste-calculated distribution with maximum intensity in the middle of the event [29], constant rainfall intensity during the time period, distribution proposed by Barszcz [30], Soil Conservation Service (SCS) Type II [31], and distribution with maximum intensity at the beginning or end of the event).

- Effective rainfall depths at given time intervals of the rainfall event according to the SCS method [31] $(\mathrm{CN}$ : curve number parameter provided by the user; $\mathrm{CN}$ parameter calculated based on the measured hydrograph).

- Characteristics of the instantaneous unit hydrograph, or IUH (characteristics calculated from Lutz's formulas [32]; characteristics calculated from SCS formulas [33]).

- Nash model parameters [22] (calculation of parameters from the established IUH characteristics, parameters provided by the user, and calculation of parameters from measured rainfall-runoff events).

- Nash's instantaneous unit hydrograph ordinates as well as unit hydrograph (UH) ordinates.

- Direct-flow hydrographs calculated in response to rainfalls with a given exceedance probability and varying duration.

- Groundwater flow hydrographs (ordinates calculated from the initial value of groundwater flow-groundwater runoff per unit area, and increase in flows over time, provided by the user).

- Total flow hydrographs.

- Maximum (peak) flows for the individual total flow hydrographs in order to establish the value of a flow with a given exceedance probability induced by a critical duration of rainfall, i.e., the duration of rainfall for which the highest peak flow value was calculated $[34,32]$.

In order to establish the probable flow in a given calculation profile, 10 rainfalls, characterized by a given exceedance probability and accepted duration times of one to 10 hours (it was assumed that critical duration times of rainfall will be less than 10 hours), were simultaneously accepted for calculation in the program. Total rainfall depths were established based on the KOSTRA DWD (German Weather Service) digital atlas [35] and read for the Losse River catchment area. The established values of rainfall were compared with corresponding rainfall values calculated from Bogdanowicz and Stachy's formula [28], prepared for the region of Poland.

Based on the established sum of rainfall depths of the individual rainfall events, the distribution rainfall depth was calculated in reference to the combined times of its duration. In order to calculate the probable flows, the normalized German Association for Water, Wastewater and Waste (DVWK) distribution [29] prepared for the geographic region of Germany was chosen, with the maximum concentration of rainfall occurring during the middle of the event.

The effective rainfall depths in the individual time frames were calculated using the SCS method as described in numerous publications [31, 34, 36-38], in which effective rainfall is dependent mainly on the type of soil (depending on the filtration coefficient of the soil, classified as belonging to soil group A, B, C, or D) and land use, as well as the soil moisture conditions in the catchment prior to occurrence of the analyzed rainfall. All of these factors are incorporated in a single $\mathrm{CN}$ parameter, the value of which was established for the individual subcatchments defined by the main calculation profiles, based on analysis using information obtained from soil maps and aerial photographs.

The value of the CN (III) parameter for the scenario of extreme flooding (Table 1) was accepted as the value calculated based on the CN (II) parameter, established in the analysis for class II of antecedent moisture conditions $(A M C)$ in the catchment (AMC II means average conditions) [34, 39], assuming that extreme flooding is caused by the occurrence of rainfall at a time when the soil in the catchment is fully saturated with rainwater, derived from events preceding the analyzed rainfall. The CN parameter for class three of antecedent moisture conditions in the catchment area (AMC III means high saturation of soil with water) was calculated using the following formula (1):

$$
C N(I I I)=\frac{23 \cdot C N(I I)}{10+0.13 \cdot C N(I I)}
$$

...where $\mathrm{CN}(\mathrm{III})$ is $\mathrm{CN}$ parameter for AMC class III in the catchment and $\mathrm{CN}(\mathrm{II})$ is $\mathrm{CN}$ parameter for AMC class II in the catchment.

Characteristics of instantaneous unit hydrograph (IUH; $\mathrm{t}_{\mathrm{A}}, \mathrm{u}_{\max }$ ) were calculated based on empirical dependencies developed by Lutz [32] for the region of Germany (the symbols are given in their original form):

$$
\begin{gathered}
t_{A}=P_{1}\left(\frac{L \cdot L_{C}}{I G^{1,5}}\right)^{0,26} \cdot e^{-0,016 U} \cdot e^{0,004 W} \\
u_{\max }=P_{2} \cdot \frac{1}{t_{A}^{P_{3}}}
\end{gathered}
$$

... where $t_{A}$ is time-to-peak of IUH (h), $u_{\max }$ is peak value of IUH $\left(h^{-1}\right), L$ is length of the main watercourse $(\mathrm{km}), \mathrm{L}_{\mathrm{C}}$ is length of the main watercourse to the geometric center of gravity of the catchment $(\mathrm{km}), \mathrm{IG}$ is average slope 
Table 4. Rainfall depth for rainfall events with a probability of $\mathrm{p}=1 \%$ and varying duration.

\begin{tabular}{|c|c|c|c|c|c|c|c|c|c|}
\hline \multicolumn{10}{|c|}{ Rainfall duration D (h) } \\
\hline 1 & 2 & 3 & 4 & 5 & 6 & 7 & 8 & 9 & 10 \\
\hline \multicolumn{10}{|c|}{ Rainfall depth acc. to KOSTRA-DWD - P (mm) } \\
\hline 56.0 & 60.6 & 63.5 & 65.7 & 67.4 & 69.0 & 70.1 & 71.3 & 72.4 & 73.3 \\
\hline \multicolumn{10}{|c|}{ Rainfall depths acc. to Bogdanowicz and Stachý - $\mathrm{P}_{\max }$ (mm) } \\
\hline 49.5 & 58.8 & 62.0 & 64.4 & 66.2 & 67.8 & 69.2 & 70.3 & 71.4 & 72.4 \\
\hline \multicolumn{10}{|c|}{ Difference in rainfall depth $\Delta \mathrm{P}(\mathrm{mm})$} \\
\hline 6.5 & 1.8 & 1.5 & 1.3 & 1.1 & 1.2 & 1.0 & 0.9 & 1.0 & 0.9 \\
\hline
\end{tabular}

of the main watercourse $(-), \mathrm{U}$ is percentage of urbanized areas $(\%), \mathrm{W}$ is percentage of forested areas $(\%), \mathrm{P}_{1}$ is parameter dependent on the watercourse roughness coefficient (-), and $\mathrm{P}_{2}$ and $\mathrm{P}_{3}$ are empirical parameters according to Lutz (-).

To determine the dependencies (2 and 3 ) presented by Lutz, information from 75 catchment areas located mainly in the southern and western regions of Germany was used. The catchments used for analyses had a surface area ranging from 3 to $236 \mathrm{~km}^{2}$, and were characterized by a percentage of forest areas ranging from 0 to $100 \%$ and urbanized areas between 0 and $85 \%$, with the average slope of the river between 0.5 and $111 \%$ [32].

Characteristics of the instantaneous unit hydrograph were also calculated from dependencies established by SCS [33] for the USA. Comparing probable flows calculated based on IUH characteristics according to SCS and Lutz made it possible to verify these two methods in the analyzed Losse catchment.

\section{Results and Discussions}

\section{Total Rainfall}

Rainfall depths $\mathrm{P}$ for rainfalls with a probability of $\mathrm{p}=1 \%$ and a duration $\mathrm{D}$ ranging from 1 to $10 \mathrm{~h}$ used to calculate probable flows for two flood scenarios (scenarios 1 and 2) have been compiled in Table 4. Rainfall depths, established based on the KOSTRA-DWD atlas for the Losse catchment area, were compared with corresponding maximum rainfall amounts $\mathrm{P}_{\max }$ calculated from Bogdanowicz and Stachy's formula for the central region of Poland. The rainfall depths established using the two above-mentioned methods were very similar. Although the values of rainfall according to KOSTRA-DWD were higher than those calculated, the differences between them $(\Delta \mathrm{P})$ were less than $2 \mathrm{~mm}$ for rainfall lasting from two to $10 \mathrm{~h}$. The smallest difference in rainfall depth was $0.9 \mathrm{~mm}$ $(\mathrm{D}=8$ and $9 \mathrm{~h}$ ), with the highest being $6.5 \mathrm{~mm}(\mathrm{D}=1 \mathrm{~h})$.

Similar analyses [40], conducted for such Polish border cities located within the area covered by the KOSTRA atlas [41] as Świnoujście, Szczecin, Kostrzyń, Gubin, Zgorzelec, and Bogatynia revealed that the intensity of rainfalls (rainfall depths) were provided in the atlas for 16 time intervals of rainfall duration (from five minutes to 72 hours) for frequencies of $\mathrm{c}=1,2,5,10,20,50$, and 100 years, respectively, which were significantly higher than in the case of those traditionally calculated in Poland using the Błaszczyk model (used most often for modeling rainfall when sizing sewer systems). The above-mentioned analyses also revealed that for a rainfall frequency of $\mathrm{c}=2,5$, and 10 years, an approx. 50\% higher intensity of rainfall is obtained when compared to the Błaszczyk model [42]. In the same study it was determined that the depths of rainfall calculated for Poland according to Błaszczyk and Stachý's model were two- to four-times lower than rainfall depths for rain lasting $15 \mathrm{~min}$. with an occurrence frequency of $\mathrm{c}=$ one year (the characteristics of one of the model rainfalls), indicated for 125 metrological stations located within Germany. The authors of the work [40] revealed a need to verify the amount of rainfall calculated using the model proposed by Bogdanowicz and Stachý for rainfalls characterized by very low frequencies $(c=50$ and 100 years), due to a not long enough (according to the authors) period of observing intensive rainfalls (1960-90).

\section{Analysis of CN Parameter}

The value of the CN parameter in the SCS method, accepted for calculating effective rainfall depth in the analyzed catchment, was established based on the analysis of the structure of land use (Table 3) and types of soil in the catchment area (Table 5). Soils classified in the B group according to SCS turned out to be the most common

Table 5. Percentage area of subcatchments characterized by different soil types.

\begin{tabular}{|c|c|c|c|}
\hline \multirow{2}{*}{$\begin{array}{c}\text { Soil type acc. to } \\
\text { SCS }\end{array}$} & $\begin{array}{c}\text { Lower } \\
\text { profile }\end{array}$ & $\begin{array}{c}\text { Upper } \\
\text { profile }\end{array}$ & $\begin{array}{c}\text { Helsa } \\
\text { profile }\end{array}$ \\
\cline { 2 - 4 } & \multicolumn{3}{|c|}{ Percentage area (\%) } \\
\hline A & - & - & - \\
\hline B & 77.2 & 80.5 & 77.1 \\
\hline C & 16.5 & 16.4 & 22.9 \\
\hline D & 6.3 & 3.1 & - \\
\hline
\end{tabular}


Table 6. Values of the CN parameter determined from analysis and accepted for calculating flood scenarios.

\begin{tabular}{|c|c|c|c|c|}
\hline \multirow{2}{*}{ Name of calculation profile } & \multirow{2}{*}{ Established parameter CN(II) (-) } & Scenario 1 $\mathrm{Q}_{\text {extreme }}$ & \multicolumn{3}{|c|}{ Scenario 2 $\mathrm{Q}_{1 \%}$} & ${\mathrm{Scenario} 3 \mathrm{Q}_{10 \%}}$ \\
\cline { 3 - 5 } & & \multicolumn{3}{|c|}{ Accepted parameter $\mathrm{CN}_{\text {calc. }}(-)$} \\
\hline Lower profile & 74.3 & 86.9 & 76.0 & 76.0 \\
\hline Upper profile & 73.4 & 86.4 & 75.0 & 75.0 \\
\hline Helsa profile & 73.7 & 86.6 & 76.0 & 76.0 \\
\hline
\end{tabular}

(77.1-80.5\%) and are characterized by an average filtration coefficient.

The established values of the $\mathrm{CN}$ (II) parameter for the subcatchments, corresponding to class two of antecedent soil moisture conditions in the catchment, ranged from 73.4 to 74.3 (Table 6). In order to calculate the probable flows for flood scenarios 2 and 3, increased values of the $\mathrm{CN}_{\text {calc. }}$ parameter were accepted (Table 6) in relation to the value of the $\mathrm{CN}$ (II) parameter (approximately two units higher). The increase in the $\mathrm{CN}$ value resulted from the comparative analysis of calculated and measured flows, on the basis of which it was determined that the accepted values of $\mathrm{CN}_{\text {calc }}$ provide for better compatibility of both flows. The value of the $\mathrm{CN}_{\text {calc. }}$ parameter calculated for class III of antecedent moisture conditions in the catchment using formula (1) was accepted for the extreme flood scenario (scenario 1).

Analyses found in the available literature indicate that in the majority of cases, empirical values of the $\mathrm{CN}$ parameter differs significantly from values of the parameter established according to the original method [43]. An analysis conducted for four agricultural catchments in various regions of Poland [34] revealed the empirical values of the $\mathrm{CN}$ parameter to be higher than values of the $\mathrm{CN}$ parameter calculated using the classical method by approximately 2.5-8 units.

\section{Verification of the Rainfall-Runoff Model}

The procedure of the R-R model presented in the work, accepted for calculating the probable flow in the Losse catchment, was verified based on analysis that involved comparing the measured and calculated flows with a model. Three values of flows measured in the Helsa profile - established based on the available data $[44,23]$ and for which the frequencies of flow occurrence $c$ (converted to probability values $p$ ) were provided - were used for verification. The established values of measured flows are compiled in Table 8 . The value of the highest flow measured in the Helsa profile, identified as extreme [44], amounted to $100.0 \mathrm{~m}^{3} \cdot \mathrm{s}^{-1}$.

Based on analyses conducted using the R-R model, flow values of a given exceedance probability, corresponding to the probability of the measured flows (Table 8 ), were established. In cases of extreme flow $\left(\mathrm{Q}_{\text {extreme }}\right)$, rainfalls with an occurrence probability of $p=1 \%$ were accepted for calculations, but the value of the $\mathrm{CN}$ parameter applied in calculations corresponded to the extreme flood scenario (Table 6).

In order to establish the highest value of maximum (peak) flow for one of the analyzed hydrographs, 10 rainfalls lasting from one to 10 hours were input into the computer program for calculations simultaneously. The calculated peak flow values of each hydrograph for the sample scenario of an extreme flood, brought on by rainfalls of varying duration, are presented in Table 7 . The highest maximum river flow value, equal to $104.2 \mathrm{~m}^{3} \cdot \mathrm{s}^{-1}$ (resulting from rainfall with a duration of $\mathrm{D}=4 \mathrm{~h}$ ), was the sought river flow value used to compare measured river flow.

Values of flow calculated based on the R-R model for the accepted parameters were subject to verification. Values of the CN parameter in the SCS method of calculating effective rainfall were shown to have the highest influence on the results of the calculations (Table 6), as well as values of instantaneous unit hydrograph (IUH) characteristics calculated for verification purposes using two methods, i.e., SCS and Lutz.

The carried out verification showed that the values of flows calculated based on empirical dependencies for establishing IUH characteristics developed by Lutz are very similar to those of corresponding flows measured in the Helsa profile (Table 8). Flows calculated using empirical dependencies according to SCS were also similar to measured flows in the case of events with a $1.11 \%$ and $25 \%$ probability of occurring, but differed significantly for the extreme event (a relative error of $23.7 \%$ ). Ultimately, dependencies proposed by Lutz were accepted to calculate probable flows used to construct flood hazard maps using the program (model).

Table 7. Peak flow values calculated in the Helsa profile for rainfalls of varying duration.

\begin{tabular}{|c|c|c|c|c|c|c|c|c|c|c|}
\hline \multicolumn{1}{|c|}{ Rainfall duration D (h) } \\
\hline 1 & 2 & 3 & 4 & 5 & 6 & 7 & 8 & 9 & 10 \\
\hline \multicolumn{8}{|c|}{ Peak flows of hydrographs Q $\left(\mathrm{m}^{3} \cdot \mathrm{s}^{-1}\right)$} \\
\hline 77.6 & 96.9 & 103.0 & 104.2 & 101.6 & 98.0 & 93.5 & 89.7 & 88.8 & 87.1 \\
\hline
\end{tabular}


Table 8. Measured and calculated flow values in the Helsa profile.

\begin{tabular}{|c|c|c|c|c|c|}
\hline \multirow{2}{*}{ No. } & \multirow{2}{*}{$\begin{array}{l}\text { Frequency } \\
\text { c (years) }\end{array}$} & \multirow{2}{*}{$\begin{array}{l}\text { Prob. } \\
\mathrm{p}(\%)\end{array}$} & \multirow{2}{*}{$\begin{array}{c}\text { Measured } \\
\text { flow } \\
\mathrm{Q}_{\text {meas. }} \\
\left(\mathrm{m}^{3} \cdot \mathrm{s}^{-1}\right)\end{array}$} & \multicolumn{2}{|c|}{$\begin{array}{c}\text { Calculated flow } \\
\mathrm{Q}_{\text {calc. }}\left(\mathrm{m}^{3} \cdot \mathrm{s}^{-1}\right)\end{array}$} \\
\hline & & & & $\begin{array}{l}\text { acc. to } \\
\text { Lutz }\end{array}$ & $\begin{array}{l}\text { acc. to } \\
\text { SCS }\end{array}$ \\
\hline 1 & $\mathrm{Q}_{\text {extreme }}$ & $\mathrm{Q}_{\text {extreme }}$ & 100.0 & 104.2 & 123.7 \\
\hline 2 & 90 & 1.11 & 55.6 & 57.0 & 51.3 \\
\hline 3 & 4 & 25 & 14.3 & 14.5 & 13.3 \\
\hline
\end{tabular}

A similar analysis conducted for a small alpine catchment in Beskid Żywiecki revealed that the application of simple conceptual models (by Nash, Snyder, Wackermann, and the geomorphological model) to covert effective rainfall of a given exceedance probability into a direct runoff hydrograph does not significantly influence peak flow, regardless of the model structure and method used to estimate the parameters [45]. Maximum flow with an exceedance probability of $p=1 \%$ calculated in this analysis using Nash's model with parameters probable based on the basic characteristics of the catchment and riverbed of the analyzed river, was very similar to the flow calculated by means of the statistical method (a relative error of $-2.6 \%$ ). In the case of the analyzed Losse catchment, the relative error for flows with a probability of $p=1.11 \%$ established using the Lutz and SCS dependencies was found to be $2.5 \%$ and $-7.7 \%$, respectively.

\section{Analysis of Probable Flows}

The accepted R-R model, the concept of which is based on the instantaneous unit hydrograph method proposed by Nash, was applied to calculate expected flows in 8 profiles located within the analyzed stretch of the Losse, limited by profiles at $\mathrm{km} 5+476$ and $7+596$ of the river (the upper and lower profiles). The probable flow values in these two sample profiles calculated for three flood scenarios (Table 1) have been presented in Table 9. Probable flow values accepted for analyses by the Department Hydraulic Engineering and Water Resources Management at the University Kassel [23], which correspond to flows calculated within the present study, are included in Table 1 for comparison. In analyses conducted by the department, the flows for the extreme flood scenario $\left(\mathrm{Q}_{\text {extreme }}\right)$ were calculated based on the product of $\mathrm{Q}_{1 \%}$ flow values and the coefficient of 1.3 accepted for the Hesse area. Probable flows, derived from the author's own analyses as well as those accepted by the department, are similar in value for $\mathrm{Q}_{1 \%}$ and $\mathrm{Q}_{10 \%}$ (scenarios 2 and 3), but much higher in the case of my own analysis for the $\mathrm{Q}_{\text {extreme }}$ scenario. Flow values used by the department to construct flood hazard maps were not subjected to verification based on measured flows.

Critical durations of rainfall $\left(\mathrm{D}_{\mathrm{cr}}\right)$ established using the program were $5 \mathrm{~h}$ in the case of the extreme flood scenario $\left(\mathrm{Q}_{\text {extreme }}\right)$ and medium probability of flood $\left(\mathrm{Q}_{1 \%}\right)$. For the $\mathrm{Q}_{10 \%}$ scenario, the critical duration of rainfall was $7 \mathrm{~h}$. The conducted analyses also showed that the times of concentration $\left(\mathrm{D}_{c}\right)$, calculated from the Kreps model as 5.4 and $5.8 \mathrm{~h}$ (for the upper and lower profiles, respectively), were similar to the established critical durations of rainfall. The results of this analysis are in accordance with DVWK findings [29], which indicate that the critical duration of rainfall is usually higher than the time of concentration but at the same time lower than its twofold value.

In order to verify the probable flows calculated using the $R-R$ model, their values were compared to those calculated by means of the analogy (extrapolation) method [46, 38]. Values of flows measured in the Helsa profile (profile-analogue) and transposed to the lower lying upper profile were used in the analysis. To calculate flows in the profile analyzed for $\mathrm{Q}_{\text {extreme }}$ and $\mathrm{Q}_{1 \%}$ scenarios, an exponent $(n=0.69)$ corresponding to the value of the regional exponent (Carpathian Mountains and uplands) for $\mathrm{p}=1 \%$ as established by Stachý and Fal was used [47]. As a result of the analysis, it was established that the values of probable flows calculated by means of the analogy method were very similar to those calculated using the $R-R$ model (Table 10).

Table 10. Flows calculated in the upper profile using the rainfallrunoff model and analogy method.

\begin{tabular}{|c|c|c|}
\hline \multirow{2}{*}{$\begin{array}{c}\text { Prob. } \\
\mathrm{p}(\%)\end{array}$} & \multicolumn{2}{|c|}{$\begin{array}{c}\text { Flow } \mathrm{Q} \\
\left(\mathrm{m}^{3} \cdot \mathrm{s}^{-1}\right)\end{array}$} \\
\cline { 2 - 3 } & Rainfall-runoff model & Analogy method \\
\hline $\mathrm{Q}_{\text {extreme }}$ & 157.9 & 156.5 \\
\hline 1 & 83.8 & 85.6 \\
\hline
\end{tabular}

Table 9. Probable flow values for flood scenarios and critical durations of rainfall.

\begin{tabular}{|c|c|c|c|c|c|c|c|c|c|}
\hline \multirow{2}{*}{ Name of calculation profile } & \multicolumn{5}{|c|}{ Results of author's own analyses } & \multicolumn{4}{|c|}{ Results acc. to University } \\
\cline { 2 - 12 } & $\mathrm{Q}_{\text {extreme }}$ & $\mathrm{D}_{\mathrm{cr}}$ & $\mathrm{Q}_{1 \%}$ & $\mathrm{D}_{\text {cr }}$ & $\mathrm{Q}_{10 \%}$ & $\mathrm{D}_{\text {cr }}$ & $\begin{array}{c}\mathrm{Q}_{\text {extreme }}: \\
\mathrm{Q}_{1 \%} \cdot 1.3\end{array}$ & $\mathrm{Q}_{1 \%}$ & $\mathrm{Q}_{10 \%}$ \\
\cline { 2 - 13 } & $\left(\mathrm{m}^{3} \cdot \mathrm{s}^{-1}\right)$ & $(\mathrm{h})$ & $\left(\mathrm{m}^{3} \cdot \mathrm{s}^{-1}\right)$ & $(\mathrm{h})$ & $\left(\mathrm{m}^{3} \cdot \mathrm{s}^{-1}\right)$ & $(\mathrm{h})$ & \multicolumn{4}{|c|}{$\left(\mathrm{m}^{3} \cdot \mathrm{s}^{-1}\right)$} \\
\hline Upper profile & 187.6 & 5 & 104.5 & 5 & 48.8 & 7 & 121.3 & 93.3 & 41.3 \\
\hline Lower profile & 157.9 & 5 & 83.8 & 5 & 38.6 & 7 & 109.1 & 83.9 & 32.4 \\
\hline
\end{tabular}


Table 11. Values of water table levels, corresponding to flows of 3 flood scenarios.

\begin{tabular}{|c|c|c|c|}
\hline \multirow{2}{*}{$\begin{array}{c}\text { Name of calcula- } \\
\text { tion profile }\end{array}$} & \multicolumn{3}{|c|}{ Water table levels } \\
(m.a.s.1.) \\
\cline { 2 - 4 } & $\begin{array}{c}\text { Scenario 1 } \\
\mathrm{Q}_{\text {extreme }}\end{array}$ & $\begin{array}{c}\text { Scenario 2 } \\
\mathrm{Q}_{1 \%}\end{array}$ & $\begin{array}{c}\text { Scenario 3 } \\
\mathrm{Q}_{10 \%}\end{array}$ \\
\hline Lower profile & 164.41 & 163.51 & 163.05 \\
\hline
\end{tabular}

\section{Calculating Water Table Levels}

Values of probable flows established for eight profiles located in the analyzed stretch of the Losse were used to calculate their corresponding water table levels in 52 profiles situated along this stretch. The WSP-ASS program, in which flow values for three flood scenarios and cross-section data for 52 profiles was provided, was used for the calculations.

Table 11 presents sample values of water table levels observed in the lower profile $(5+476 \mathrm{~km})$ that correspond to the probable flows for three flood scenarios. The water table levels in the lower profile have been graphically illustrated in relation to the analyzed flood scenarios in Fig. 3.

\section{Flood Hazard Maps}

A digital terrain model (DTM) was composed using ArcMap in order to construct flood hazard maps containing elevation points for 52 profiles on the analyzed stretch of the Losse River (from $5+476$ to $7+596 \mathrm{~km}$ ). Based on the cross-sections of 52 profiles and their corresponding levels of the water table, the extent of flooding and water depths for three flood scenarios were calculated using standard ArcMap tools as well as those programmed into the software. An example of the constructed flood hazard map, portraying the spatial distribution of water depths in the area encompassed by the catchment for the extreme

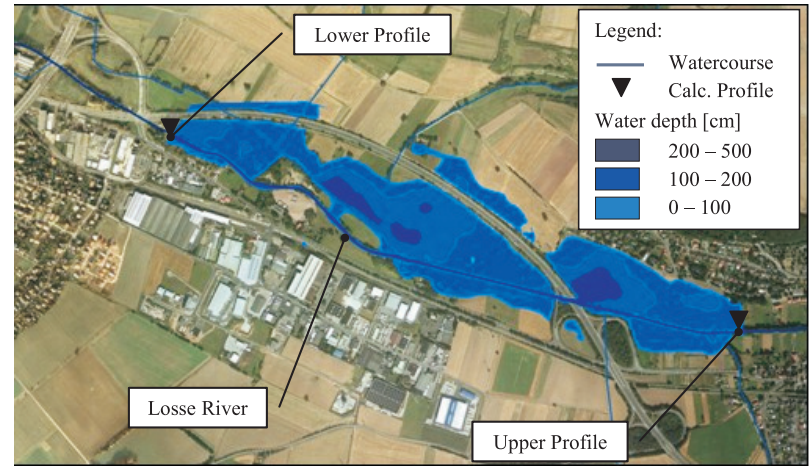

Fig. 4. Spatial distribution of water depth for extreme flood scenario (aerial photograph: HLUG [48]).

flood scenario, is presented in Fig. 4 (with an aerial photograph used for the backdrop).

An assessment of flood hazard and risk in the analyzed area of the Losse River catchment was carried out based on information derived from the constructed flood map (Fig. 4). Based on this assessment it was established that maximum water depths in the catchment area were approximately $5 \mathrm{~m}$. According to the methodology developed by the National Council of Water Management $[49,50]$, water depths greater than $4 \mathrm{~m}$ displayed on flood hazard maps are representative of areas posing a high risk to humans along with a high risk of extensive damage. The types of land use and area that they cover within the flood zone in the case of an extreme flood scenario are compiled in Table 12.

The potential occurrence of the extreme flood scenario will cause flooding of mainly meadows $(92.5 \%)$ and forest areas $(4.1 \%)$. Arable land, industrial and residential areas, and areas occupied by the water treatment plant are also in the flood zone, causing adverse consequences to business activities, the infrastructure, the environment, and human health and life.

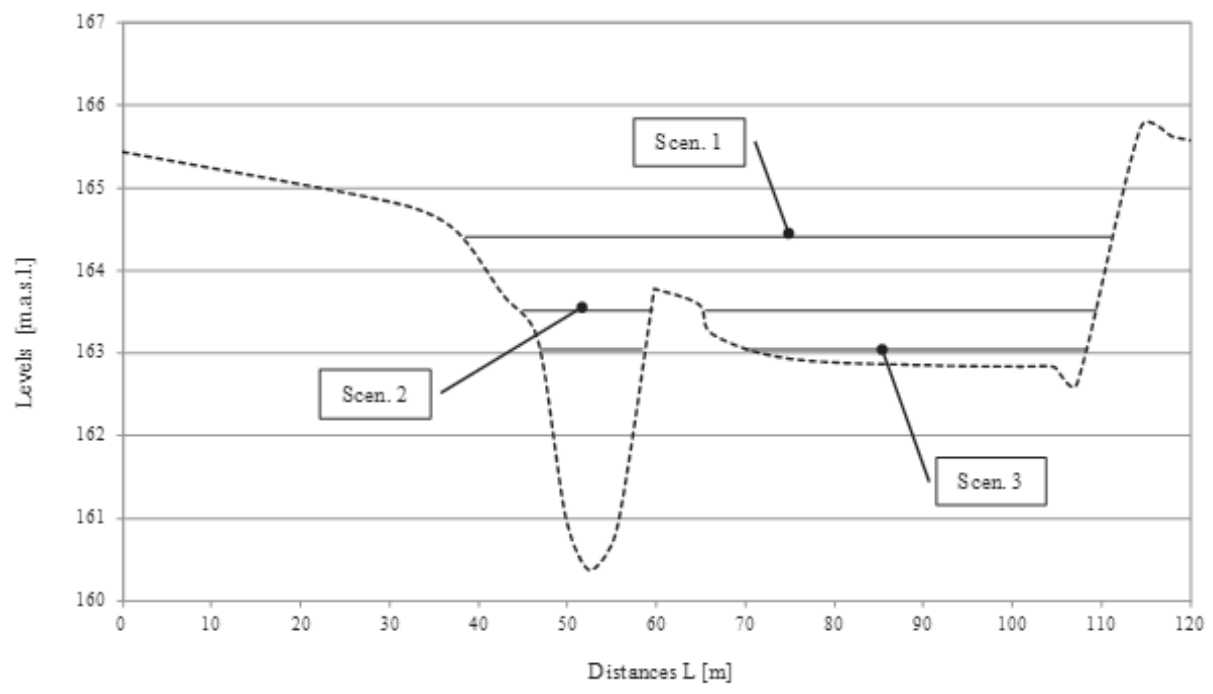

Fig. 3. Water table levels in the lower profile for three flood scenarios. 
Table 12. Values of areas with different types of land use within the analyzed flood zone for the extreme flood scenarios.

\begin{tabular}{|c|c|}
\hline Type of land use & Percentage area (\%) \\
\hline Meadows & 92.5 \\
\hline Forest areas & 4.1 \\
\hline Industrial areas & 1.0 \\
\hline Arable land & 1.0 \\
\hline Residential areas & 0.8 \\
\hline Water treatment plant & 0.4 \\
\hline Recreational areas & 0.2 \\
\hline
\end{tabular}

\section{Summary and Conclusions}

This article presents the procedure of the rainfallrunoff model based on the instantaneous unit hydrograph (IUH) method used to calculate probable flows in eight profiles of the Losse River (on the stretch between the upper and lower profile) for three flood scenarios $\left(Q_{\text {extreme }}\right.$, $\mathrm{Q}_{1 \%}$, and $\mathrm{Q}_{10 \%}$ ). Verification of the model was performed based on three values of flows with a known exceedance probability $\left(\mathrm{Q}_{\text {extreme }}, \mathrm{Q}_{1.11 \%}\right.$, and $\left.\mathrm{Q}_{25 \%}\right)$ as measured in the Helsa profile. A computer program developed by the author was used to conduct the analyses, enabling the flows to be simultaneously calculated for all analyzed profiles in response to 10 rainfalls of varying duration and a given exceedance probability.

The established values of probable flows were recalculated for corresponding water table levels using the WSP-ASS model. Based on the water table levels and terrain elevation data from the digital terrain model, the extent of the flooded area and water depths were calculated for each of the three scenarios. The results of these calculations, carried out using the ArcMap program, were displayed in the form of a flood hazard map. The conducted analyses enable the following conclusions to be drawn:

- Rainfall depths of a given exceedance probability and varying duration, established using the KOSTRADWD atlas for the analyzed catchment in Germany, are very similar to corresponding maximum total rainfalls calculated using the model proposed by Bogdanowicz and Stachý for central Poland.

- The values of the CN(II) parameter determined using the SCS method of calculating effective rainfall depth (based on the analysis of land use and soil type) for the analyzed subcatchments for class II of antecedent moisture conditions in the catchment ranged from 73.4 to $74.3(-)$.

- As a result of the comparative analysis of river flows calculated using the $R-R$ model and measured in the Helsa profile, it was established that the values of the $\mathrm{CN}$ (II) parameter are lower than they should be. In order to calculate the probable flows for two flood scenarios $\left(\mathrm{Q}_{1 \%}\right.$ and $\left.\mathrm{Q}_{10 \%}\right)$, increased values of the $\mathrm{CN}$ parameter, which were approximately two units higher when compared to $\mathrm{CN}(\mathrm{II})$, were accepted. The value of the $\mathrm{CN}(\mathrm{III})$ parameter calculated for class III of antecedent moisture conditions in the catchment was used for the extreme flood scenario.

- Values of probable flows, calculated using empirical dependencies to determine IUH characteristics according to Lutz, were very similar to their corresponding values of measured river flows. Basing calculations on dependencies according to Lutz resulted in a higher compatibility of calculated and measured flows than when applying formulas developed by SCS.

- Critical durations of rainfall were found to be $5 \mathrm{~h}$ in the case of the $\mathrm{Q}_{\text {extreme }}$ and $\mathrm{Q}_{1 \%}$ scenarios, and $7 \mathrm{~h}$ for the $\mathrm{Q}_{10 \%}$ scenario. The times of concentration, calculated from the Kreps formula as 5.4 and $5.8 \mathrm{~h}$ (for the upper and lower profile, respectively), were similar to the critical durations of rainfall.

- Values of probable flows for the $\mathrm{Q}_{\text {extreme }}$ and $\mathrm{Q}_{1 \%}$ scenarios, calculated using the analogy (extrapolation) method on the basis of river flows measured in the Helsa profile for the upper profile, were very similar to their corresponding flows that were calculated using the $R-R$ model.

- On the basis of the constructed flood hazard map, it was established that the maximum depths of water for the $\mathrm{Q}_{\text {extreme }}$ scenario were equal to approximately $5 \mathrm{~m}$ and so within the range of water depths of over $4 \mathrm{~m}$ - indicating areas of high risk to people and with a high risk of the occurrence of severe damage.

- The potential occurrence of an extreme flooding scenario will result in the flooding of areas used as meadows (92.5\%), forests, arable land, industrial areas, residential areas, and areas of the water treatment plant, causing adverse consequences to business activity, the infrastructure, the environment, and the health and life of humans.

\section{Acknowledgements}

The author would like to thank the Department of Hydraulic Engineering and Water Resources Management at the University of Kassel for their useful information and technical support. The author also thanks the German Academic Exchange Service (DAAD) for financial support.

\section{References}

1. Directive 2007/60/EC of the European Parliament and Council of 23 October 2007 on the assessment and management of flood risk. Official Journal of the European Union No. L 288/27, 6.11.2007.

2. Water Law of 5 January 2011. Journal of Laws No. 32, item 104, 2011 [In Polish].

3. LABEL (EU Project on river Labe-Elbe). Available at: http:// www.label-eu.eu. 2011. 
4. FLOOD WISE (Water Information System for Europe). Available at: http://flood-wise.eu. 2011.

5. Regulation of the Minister of Environment, Minister of Transport, Construction and Maritime Economy, Minister of Administration and Digitalization, and Minister of Internal Affairs of 22 January, 2013 on developing flood hazard and flood risk maps. Journal of Laws 2013, item 104, 2013 [In Polish].

6. KJELLGREN S. Exploring local risk managers` use of flood hazard maps for risk communication purposes in BadenWürttemberg. Nat. Hazards Earth Syst. Sci. 13, 1857, 2013.

7. MÜLLER U. Implementation of the Flood Risk Management Directive in Selected European Countries. Int. J. Disaster Risk Sci. 4 (3), 115, 2013.

8. LAWA (German Working Group on Water Issues of the Federal States and the Federal Government). Recommendations for the Establishment of Flood Hazard Maps and Flood Risk Maps. Dresden, 2010 [In German].

9. LAWA (German Working Group on Water Issues of the Federal States and the Federal Government). Recommendations for the Establishment of Flood Risk Management Plans. Dresden, 2010 [In German].

10. DYSARZ T., WICHER-DYSARZ J., SOJKA M. Assessment of the Impact of New Investments on Flood Hazard-Study Case: The Bridge on the Warta River near Wronki. Water 7, 5752, 2015.

11. SARHADI A., SOLTANI S., MODARRES R. Probabilistic flood inundation mapping of ungauged rivers: Linking GIS techniques and frequency analysis. J. Hydrol. 458-459, 68, 2012.

12. AGGETT G.R., WILSON J.P. Creating and coupling a highresolution DTM with a 1-D hydraulic model in a GIS for scenario-based assessment of avulsion hazard in a gravelbed river. Geomorphology 113 (1), 21, 2009.

13. BEILICCI R., BEILICCI E. Advance hydraulic modeling using HEC-RAS, Baraolt River, Romania. Research Journal of Agricultural Science 46 (1), 19, 2014.

14. ZHONG G.H., LIU S.G., HAN C., HUANG W. Urban flood mapping for Jiaxing City based on hydrodynamic modeling and GIS analysis. Journal of Coastal Research, Special Issue, 68, 168, 2014.

15. REMO J.W.F, CARLSON M., PINTER N. Hydraulic and flood-loss modeling of levee, floodplain, and river management strategies, Middle Mississippi River, USA. Nat Hazard 61, 551, 2012.

16. MOEL H., AERTS J.C.J.H., KOOMEN E. Development of flood exposure in the Netherlands during the $20^{\text {th }}$ and $21^{\text {st }}$ century. Global Environmental Change 21 (2011), 620, 2011.

17. ALAGHMAND S., bin ABDULLAH R., ABUSTAN I., VOSOOGH B. GIS-based river flood hazard mapping in urban area (a case study in Kayu Ara River Basin, Malaysia). Int. J. Eng. Technol. 2 (6), 488, 2010.

18. HE Y.P., XIE H., CUI P., WEI F.Q., ZHONG D.L., GARDNER J.S. GIS-based hazard mapping and zonation of debris flows in Xiaojiang Basin, southwestern China. Environ. Geol. 45(2), 286, 2003.

19. FERNANDEZ D., LUTZ M. Urban flood hazard zoning in Tucumán Province, Argentina, using GIS and multicriteria decision analysis. Eng. Geol. 111(1-4), 90, 2010.

20. BAJABAA S., MASOUD M., AL-AMRI N. Flash flood hazard mapping based on quantitative hydrology, geomorphology and GIS techniques (case study of Wadi Al Lith, Saudi Arabia). Arab. J. Geosci. 7, 2469, 2014.

21. KLEMEŠOVÁ K., KOLÁŘ M., ANDRÁŠKO I. Using GIS in the flood management - flood maps (Troubky, Czech Republic). Geographia Technica 09(2), 44, 2014.
22. NASH J.E. The form of the instantaneous unit hydrograph. IAHS 59, 202, 1957.

23. REGIERUNGSPRÄSIDIUM KASSEL, UNIVERSITÄT KASSEL. Flood risk management plan for the catchment area of the Hessian Fulda (Summary). Kassel, 164, 2010 [In German].

24. THEOBALD S., ROLAND F., KREIL A., MARBURGER M. Flood risk management planning for the catchment area of the Hessian Fulda. Korrespondenz Wasserwirtschaft 2011, 9 (4), 499, 2011 [In German].

25. BARSZCZ M., THEOBALD S., RÖTZ A. Methodology of flood risk management plan for the Fulda river catchment area in Germany. Gospodarka Wodna 1, 12, 2013 [In Polish].

26. BARSZCZ M. Evaluation of suitability of the conceptual Nash model for the simulation a flow hydrograph in a urbanized catchment considering rainfall depth scenarios. Sci. Rev. Eng. Env. Sci. 64, 113, 2014 [In Polish].

27. CIEPIELOWSKI A., DAZBKOWSKI L.SZ. Methodology of calculating maximum flows in small river catchments (with examples). Publishing House of Projprzem-EKO, Bydgoszcz, 2006 [In Polish].

28. BOGDANOWICZ E., STACHÝ J. Maximum rainfalls in Poland, design characteristics. Materiały badawcze IMGW 23, Hydrologia i Oceanologia 85, 1997 [In Polish].

29. DVWK (German Association for Water, Wastewater and Waste). Instructions for use of rainfall-runoff models in small watersheds. Regeln 113, Verlag Paul Parey, Hamburg, Vol. II, 1984 [In German].

30. BARSZCZ M. Normalized rainfall depth distributions during rainfalls in the area of experimental catchment in Warsaw. Woda-Środowisko-Obszary Wiejskie, Vol. 12, 3 (39), 27, 2012 [In Polish].

31. SCS (Soil Conservation Service). National Engineering Handbook. Sec. 4, Hydrology, U.S. Department of Agriculture, Washington, D.C., 1985.

32. LUTZ W. Calculation of flood flows using field characteristics. Institute of Hydrology and Water Managament. University of Karlsruhe (TH), 1984 [In German].

33. USDA-SCS (U.S. Department of Agriculture, Soil Conservation Service). Engineering field manual. Chapter 2: Estimating runoff and peak discharges, 1989.

34. IGNAR S. Methodology of calculating flood flows in unobserved catchment areas. Rozprawy Naukowe i Monografie, SGGW Publishing, Warszawa, 56, 1993 [In Polish].

35. KOSTRA-DWD. German Weather Service Abt. Hydrometeorology, Rainfall amounts (Losse), 2005 [In German].

36. WANIELISTA M., KERSTEN R., EAGLIN R. Hydrology, Water quantity and quality control. John Wiley \& Sons, Inc, 1997.

37. OKOŃSKI B. Modeling direct runoff depending on the state of the forest catchment cover. Seria Rozpr. Nauk. Publishing House of Agricultural Academy, Poznań, 374, 2006 [In Polish].

38. BYCZKOWSKI A. Hydrology. SGGW Publishing, Warszawa, II, 333, 1996 [In Polish].

39. MISHRA S.K., SINGH V.P. Soil Conservation Service Curve Number (SCS-CN) Methodology. Kluwer Academic Publishers, Dordrecht, 2003.

40. KOTOWSKI A., KAŹMIERCZAK B., DANCEWICZ A. Modeling of rainfalls for the purpose of dimensioning sewage systems. Committee of Civil Engineering Sciences of Polish Academy of Sciences, 128, 2010 [In Polish].

41. IMHOFF K., IMHOFF K.R. Construction of sewage in cities and wastewater treatment. Publishing House of Projprzem-EKO, Bydgoszcz, 1996 [In Polish].

42. BŁASZCZYK W., ROMAN M., STAMATELLO H. Sewage 
system. Arkada Publishing, Warsaw, Vol. I, 1974 [In Polish].

43. OKOŃSKI B., MILER A.T. Adapting the SCS-CN method for calculating effective rainfall in forest catchments. Monografie Komitetu Inżynierii Środowiska Polskiej Akademii Nauk I (68), 143, 2010 [In Polish].

44. HLUG (Hessian Agency for Environment and Geology). Water gauge station - Helsa. Available at: http://www.hlug. de/static/pegel/static/stat_156869.htm?entryparakey=W. 2015.

45. WIĘZIK B. Maximum annual flows of given exceedance probability in small uncontrolled catchments. Monografie Komitetu Inżynierii Środowiska Polskiej Akademii Nauk I (68), 153, 2010 [In Polish].

46. SHP (Association of Polish Hydrologists). Methodology of calculating maximum flows and rainfalls of given exceedance probability for controlled as well as uncontrolled catch- ments, and identifying rainfall-runoff transformation models. Work commissioned by the National Water Management Authority, Warszawa, 2009 [In Polish].

47. STACHÝ J., FAL B. The rules for calculating the maximum probable flows. Prace Inst. Bad. Dróg i Mostów, 3, 1984 [In Polish].

48. HLUG (Hessian Agency for Environment and Geology). Available at: www.hlug.de/start/wasser/hochwasser.html. 2015.

49. WŁODARCZYK A., KĘSY R. Methodologies of preparing flood hazard maps - main assumptions. Monografie Komitetu Inżynierii Środowiska Polskiej Akademii Nauk I, (68), 309, 2010 [In Polish].

50. KZGW (National Water Management Authority). Methodology of Flood Hazard and Risk Maps Elaboration. KZGW, Warszawa, 2009 [In Polish]. 